\title{
Optimization and Quality Evaluation of Pasta Utilizing Corn Grits By-Product (Hominy Flour)
}

\author{
M. Ram Mohan ${ }^{1 *}$, N. Sahana ${ }^{2}$ and Bhaswati Bhattacharya ${ }^{3}$ \\ ${ }^{1}$ Food Safety and Quality Management, National Institute of Food Technology \\ Entrepreneurship and Management, Kundli, Haryana-131028, India \\ ${ }^{2}$ Food Technology, Tamilnadu Veterinary and Animal Sciences University \\ College of food and Dairy Technology, Kodvelli, Chennai-52, India \\ ${ }^{3}$ Department of Basic and Applied Sciences, National Institute of Food Technology \\ Entrepreneurship and Management, Kundli, Haryana-131028, India \\ *Corresponding author
}

\begin{tabular}{|l|}
\hline Ke y w o r d s \\
Replacement- \\
$\begin{array}{l}\text { Dietary fibre- } \\
\text { Hominy flour- } \\
\text { Quality } \\
\text { Characterisation }\end{array}$ \\
\hline Article Info \\
\hline $\begin{array}{l}\text { Accepted: } \\
\text { 20 August } 2019 \\
\text { Available Online: } \\
\text { 10 September } 2019\end{array}$ \\
\hline
\end{tabular}

\section{A B S T R A C T}

In this study, corn grit by-product (hominy flour) is used as a replacement of durum wheat semolina in pasta (macaroni). Hominy flour is used as a feed ingredient in livestock, poultry, etc. and is found to be a good source of protein and dietary fibre. Trials were made in such a way to replace durum wheat semolina such as $10 \%, 20 \%, 30 \%, 40 \%$ and $50 \%$ and quality assessment along with typical characteristics of pasta were tested. Different Pasta blends have been compared with the control pasta and quality characterisation of pasta is evaluated. It has been found that $30 \%$ replacement has good sensory acceptance with $9.45-9.57 \%$ of Dietary fibre.

\section{Introduction}

In the current era of globalization there is a worldwide shift in the diet plan. This shift is from a diet dominated by staples-mainly coarse grains and other partially processed grains, vegetables and legumes to one where processed foods predominate and animal source foods represent a far greater proportion of all calories (Drewnowski A, 1997). The diets which we consume nowadays are high in fats, saturated fatty acids, sugar and salt. Cumulative effect of lifestyle and food habits has manifested itself as obesity, hypertension, high cholesterol, cardiovascular disease, diabetes, impaired pancreatic function and osteoporosis. Thus, the time is right for optimizing health by the use of functional foods. Whole grains contain endosperm, germ, and bran. Whole grains are rich in nutrients 
and phytochemicals with more known, documented health benefits (Slavin J, 2004)and are rich in dietary fibre, resistant starch, and oligosaccharides. It is also rich in antioxidants including trace minerals and phenolic compounds and these compounds have been linked to preventing diseases. In order to maintain these components in the end-products, whole grain flours and/or fortified flours are recommended for the production of health enhancing foods or functional foods which has great demand among current generation due to change in lifestyle.

With increase in urbanization, industrialization and change in life style, consumers are looking forward at snacks and foods which are more convenient to process which is also good source of nutrition and currently demand for low-calorie and lowsugar foods are in hike now. Nutritional benefits are particularly enhanced when grains are used for food preparations.

Production of formulated food such as pasta with high protein and fibre can give many health benefits to people. Pasta is a good carrier to supply nutrition for the healthconscious consumers. Pasta is one of the greatest processed food made from grains. The term "Pasta" originated from Greek and Latin which means "Barley Porridge" in Greek and "Dough Pastry cake" in Latin. In Italy it is termed as "Paste" because of the way it is made by mixing flour, water and ingredients required. There is a typical thinking that Pasta is invented in Italy but the first recorded reports of people consuming pasta is from China as early as around 5000B.C.Pasta may have its origin in Asia and Mediterranean but growing popularity of pasta has made it a healthy food worldwide. Pasta products such as macaroni, spaghetti and noodles are very popular in Europe and in Western Hemisphere. Approximately 13.6 million tons of pasta is produced worldwide with an estimate of 100,000 tons production in India (www.pasta-unafpa.org).As per International Pasta organization, 600 different shapes of Pasta are produced throughout the globe.

In India, the use of pasta products particularly noodles have increased to more than unexpected level and even market competition has increased significantly to another level.

Important quality of pasta is that it liberates the sugars slowly, which body needs progressively. In India Pasta products such as macaroni, spaghetti, vermicelli and noodles are manufactured from semolina and flour produced from durum wheat. This is because wheat proteins such as gliadins and glutenins which have properties in which interaction between semolina and other components, mainly lipids, to form a very specific viscoelastic lipoprotein complex called gluten when mixed with semolina and water are mixed together (Kaur G, 2009). These products are becoming popular in current lifestyle because they are healthy, tasty and convenient for transportation and preparation(Cubadda R, 1994)

In India, Corn (Zea mays) has become the third most important food grain after wheat and rice. It has high-energy value and is used for human food and animal feed. Corn flour is used to make nutritious products which are highly palatable and are easily digested by the body.

When taken at different intervals, its proven that it helps to clean the colon. The use of maize also helps to combat the effects of certain cancers, as it reduces the development of colon cancer. In view of the aforesaid points, the present study was focused on the use of un-exploited corn grits by-product for production of ready-to-cookpasta product using cold extrusion technology. 


\section{Materials and Methods}

\section{Raw material}

Durum wheat semolina was purchased from local market (Kundli) and the Corn grit byproduct was collected from a Corn processing industry (Sun-up Agro processing Pvt Ltd). It was grinded, sieved and the particle size was reduced to $250 \mu$ using sieve.

\section{Equipments}

Laboratory scale pasta maker (La Monferrina, Italy) was used for making pasta and Lab scale tray dryer was used in this.

\section{Optimum Cooking Time}

Optimum cooking time was determined using AACC(2000). Trials made $\mathrm{T} 1=10 \%, \mathrm{~T} 2=20 \%$, $\mathrm{T} 3=30 \%, \mathrm{~T} 4=40 \%, \mathrm{~T} 5=50 \%$ and control (semolina 100\%) were used for measuring the optimum cooking time required to cook pasta. $10 \mathrm{~g}$ pasta sample was weighed and boiled in $200 \mathrm{ml}$ of distilled water.

\section{Cooking loss}

Cooking loss is the amount of loss in pasta happened during cooking and it was measured as $\%$ loss. The desirable characteristic of pasta is that cooking loss should be less than $12 \%$.

It was calculated by transferring the water which was used for cooking the pasta into predried, weighed beaker and the water was allowed to get dried completely in a hot-plate. It was then allowed to cool in a desiccator. Final weight of the beaker was noted. Cooking loss was calculated using the formula below:

$$
\text { Cooking loss }(\%)=\frac{100 *(W 2-W 1)}{W}
$$

Where W1 is weight of the empty beaker, W2 is the weight of the beaker after drying and $\mathrm{W}$ is the weight of the sample taken in gram.

\section{Water absorption index}

Water absorption of pasta was calculated by weighing the raw pasta and cooking the pasta to optimum cooking time. The weight of cooked pasta was also noted. It was calculated using the formula:

$$
\begin{aligned}
& \text { Water absorption index }(\%) \\
& =\frac{\text { weight of cooked pasta-weight of raw pasta }}{\text { weight of raw pasta }} * 100
\end{aligned}
$$

\section{Swelling index}

It is the water uptake of dry pasta per gram. It was done by drying the cooked pasta at $105^{\circ} \mathrm{C}$ until the constant weight was obtained. It was evaluated using the formula:

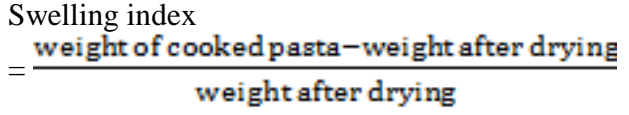

\section{Moisture content}

Moisture content was determined by the gravimetric method as described in AOAC (1990)

\section{Ash}

Muffle furnace was used to determine the ash content in the product as described in AOAC, 1990.The total ash content was determined by weighing accurately about $5 \mathrm{~g}$ of the sample in previously heated and cooled silica/porcelain dish. The samples were charred/pre-heated over a hot plate or flame and then placed in muffle furnace at $545 \pm 5^{\circ} \mathrm{C}$ forthree hours or till ash is obtained.

$$
\operatorname{Ash}(\%)=\frac{W 2-W 1}{W} * 100
$$


Where W1 is empty weight of the crucible, W2 is the weight of the crucible and sample after ashing and $\mathrm{W}$ is the weight of the sample taken in gram

\section{Crude Protein}

Dry pasta sample was grinded using mortar and pestle. $1 \mathrm{~g}$ of the sample was taken in Kjeldahl tube. The kjeldahl tube was placed in micro-digestion unit. Once the digestion was completed, the kjeldahl tube was placed in distillation unit. The various nitrogenous compounds were converted into ammonium sulphate by boiling with concentrated sulphuric acid. The ammonium sulphate formed was decomposed with an alkali $(\mathrm{NaOH})$ and the ammonia liberated was absorbed in excess of standard solution of acid and then back titrated with standard alkali. The nitrogen value was multiplied by 6.25 to obtain the protein content.

$=\frac{\text { Protein (\%) }}{\text { sampleweight } \$ 1000}$

\section{Crude fat}

Dry pasta sample was crushed and grinded using mortar and pestle. $5 \mathrm{~g}$ of the powdered sample was taken in what mann filter paper and placed in pre-dried, weighed glass thimble. The thimble was then filled with $3 / 4^{\text {th }}$ of petroleum ether and the Soxhlet unit was switched on.

Once the process was completed, the glass thimble was placed in hot air oven at 80$85^{\circ} \mathrm{C} / 30 \mathrm{~min}$. this process was done to evaporate the residues of petroleum ether if present any. The final weight of the thimble was noted. Crude fat was calculated using the formula:

Crude fat $(\%)=\frac{\text { final weight- initial weight }}{\text { sample weight }} * 100$

\section{Dietary fibre}

For estimation of dietary fibre IS 11062:1984 method was followed. Samples were sent to Apex Testing and Research laboratory, New Delhi.

The total dietary fibre was estimated using the formula

Total dietary fibre

$=\frac{(\text { Mass of soluble fraction+Mass of Insoluble fraction) }}{\text { Mass of sample }}$

Colour

Colour of the Pasta samples at different trials were measured individually by using hand hold Chroma-meter (KONICA MINOLTA, CR-400, JAPAN) and was read as L*, a*and $\mathrm{b}^{*}$. $\mathrm{L}^{*}$ represents light dark spectrum with a range from 0 (Black) to 100 (white). While $a^{*}$ is the red-green spectrum with a range from 60 (green) to +60 (red) and $b^{*}$ indicates yellow- blue spectrum with a range from -60 (blue) to +60 (yellow). Initially the calorimeter was calibrated by placing the tip of measuring head flat against the surface of the white calibrated place. After this the values of $\mathrm{L}^{*}, \mathrm{a}^{*}, \mathrm{~b}^{*}$ and $\Delta \mathrm{E}^{*}$ of pasta was measured as total colour difference $(\Delta \mathrm{E})$ was calibrated as Equation:

$\Delta \mathrm{E}^{*}=\sqrt{((\mathrm{L} *) 2+(\mathrm{a} *) 2+(\mathrm{b} *) 2)}$

\section{Results and Discussion}

The effect of cooking over the pasta quality in terms of cooking loss, water absorption power and swelling index of the pasta made out of durum wheat semolina and Corn grits byproduct is given in Table 1. Significant variation was observed in the minimum cooking time of pasta. Control pasta (100\% durum wheat semolina) took 07:05min for complete gelatinization of starch on cooking. 
It was determined as the time when the white inner core of the pasta disappeared when placed/compressed between two glass slides. Decrease in cooking time was observed as the amount of wheat semolina decreased and proportion of Corn grit by-product is increased.

In Pasta Formation, the protein matrix is crucial factor. If it is being disrupted by adding other additives, it will negatively affect cooking quality leading to a decreased optimum cooking time (Chillo S et al., 2007 and Chillo $\mathrm{S}$ et al., 2008b) and it also leads to increase in cooking loss (Ugarcic-Hardi Z et al., 2003 and Sabanis D et al., 2006).It is evident from table 2, that the optimum cooking time gets decreased if the semolina is replaced by Corn grits by-product and it is also clear that the cooking loss gets increased, swelling index and Water absorption index also gets increased after replacement of durum wheat semolina. Water absorption index is increased as the semolina is replaced. As water absorption increases it leads to relatively stable dough.

There is a significant rise in the volume expansion over control (100\% wheat) pasta was observed which is described in Table 1. As the level of Corn grit by-product is increased in the blends the protein content also increased.

Significant differences were observed for colour values of $\mathrm{L}^{*} \mathrm{a}^{*} \mathrm{~b}^{*}$ among the Pasta which was shown in table 2 . $\mathrm{L}^{*}$ value corresponds to lightness of the product. Lightness of pasta decreased with the addition/replacement of Corn grits by-product from $10 \%$ to $50 \% \quad(68.84 \pm 0.04$ to $59.40 \pm 0.10)$. The parameter $\mathrm{a}^{*}$ denotes the balance between green (negative values) and red (positive values).As the addition of corn grits by-product along with semolinait increases $\mathrm{a}^{*}$ value, it might be due to addition of proteins, which causes a* parameter to shift towards small positive (Ziobro et al., 2013).The $b^{*}$ is the function of the green blue difference. Positive $b^{*}$ indicates yellowness, negative $b^{*}$ indicates blueness. As the percentage of Corn grit by-product is increased in the blends, the $b^{*}$ value also increased from $21.63 \pm 0.16$ to $22.88 \pm 0.14$.

The hue angle is used to characterize colour in food product. Perfect angle of $90^{\circ}$, represents the light-yellow colour of the product. Addition of corn grits to semolina decreased the darkness of pasta as compared to control.

Mean sensory panel score for the pasta prepared by substituting corn grit by-product at different levels were evaluated by semitrained panel of 25 judges on 9-point hedonic scales given in Table 3 . The proximate composition of the raw material along with the Control and trail samples was given in table 4 .

The results exhibited anon- significant difference between the trials. Crude protein was found to be high in pasta incorporated with corn girt by-product than the pasta made with durum wheat.

The Corn grit by-product Pasta which is used for replacement of semolina was comparable with control pasta (100\% Durum wheat semolina) in terms of physicochemical properties and acceptability.

Corn grits by-product can be added up to 3040 percent without adversely affecting the quality attributes of pasta. Therefore, byproduct utilisation for making of nutritious pasta is a newer direction for convenience and value addition 
Table.1

\begin{tabular}{|l|c|c|c|c|}
\hline Sample & $\begin{array}{c}\text { Optimum cooking } \\
\text { time (min) }\end{array}$ & Cooking loss $(\%)$ & $\begin{array}{c}\text { Water absorption index } \\
(\mathbf{\%})\end{array}$ & $\begin{array}{c}\text { Swelling index } \\
\text { g/g }\end{array}$ \\
\hline Control & $07: 05 \pm 0.07$ & $5.76 \pm 0.21$ & $107.6 \pm 0.19$ & $2.8 \pm 0.25$ \\
\hline T1-10\% & $06: 25 \pm 0.09$ & $7.78 \pm 0.12$ & $115.7 \pm 0.05$ & $3.5 \pm 0.20$ \\
\hline T2-20\% & $06: 05 \pm 0.09$ & $9.24 \pm 0.15$ & $120.2 \pm 0.25$ & $4.4 \pm 0.22$ \\
\hline T3- 30\% & $05: 53 \pm 0.10$ & $11.41 \pm 0.05$ & $124.4 \pm 0.12$ & $4.8 \pm 0.29$ \\
\hline T4- 40\% & $05: 41 \pm 0.02$ & $13.16 \pm 0.10$ & $132.1 \pm 0.09$ & $4.2 \pm 0.22$ \\
\hline T5- 50\% & $05: 25 \pm 0.05$ & $15.27 \pm 0.20$ & $134.9 \pm 0.11$ & $4.3 \pm 0.18$ \\
\hline F Value & $2.73 *$ & $5.12 * *$ & $9.74 * *$ & $2.59 *$ \\
\hline
\end{tabular}

@ Average of six trials

NS-Non-Significant $(\mathrm{P}>0.05 ; *$ - Significant $(\mathrm{P}<0.05) ; * *$-Highly significant $(\mathrm{P}<0.01)$; Mean Values bearing different superscripts in a row differ significantly

Table.2

\begin{tabular}{|c|c|c|c|c|c|}
\hline \multirow[t]{2}{*}{ Sample } & \multicolumn{3}{|c|}{ Mean Tri-stimulus Colour Values } & \multirow[t]{2}{*}{$\Delta \mathbf{E}^{*}$} & \multirow[t]{2}{*}{ Hue Angle ( $\left.{ }^{\circ}\right)$} \\
\hline & $\mathbf{L}^{*}$ & $\mathbf{a}^{*}$ & $\mathbf{b}^{*}$ & & \\
\hline $\begin{array}{l}\text { Control }(\mathbf{1 0 0 \%} \\
\text { semolina) }\end{array}$ & $68.44 \pm 0.09$ & $0.45 \pm 0.07$ & $20.96 \pm 0.18$ & $35.4 \pm 0.12$ & $88.76 \pm 0.24$ \\
\hline $\begin{array}{l}\mathrm{T} 1 \\
10 \%\end{array}$ & $68.84 \pm 0.04$ & $0.07 \pm 0.15$ & $21.63 \pm 0.16$ & $35.3 \pm 0.18$ & $89.79 \pm 0.21$ \\
\hline $\begin{array}{l}\mathrm{T} 2 \\
20 \%\end{array}$ & $66.81 \pm 0.15$ & $1.40 \pm 0.10$ & $23.72 \pm 0.15$ & $38.0 \pm 0.21$ & $86.62 \pm 0.17$ \\
\hline $\begin{array}{l}\text { T3 } \\
\text { 30\% }\end{array}$ & $62.85 \pm 0.01$ & $2.10 \pm 0.05$ & $24.08 \pm 0.10$ & $42.2 \pm 0.17$ & $85.01 \pm 0.16$ \\
\hline $\begin{array}{l}\text { T4 } \\
40 \%\end{array}$ & $61.58 \pm 0.10$ & $1.81 \pm 0.14$ & $21.56 \pm 0.15$ & $42.4 \pm 0.13$ & $85.20 \pm 0.13$ \\
\hline $\begin{array}{l}\text { T5 } \\
\mathbf{5 0 \%}\end{array}$ & $59.40 \pm 0.10$ & $1.55 \pm 0.13$ & $22.88 \pm 0.14$ & $38.1 \pm 0.12$ & $86.11 \pm 0.12$ \\
\hline F Value & $6.97 *$ & $4.25^{*}$ & $4.46^{*}$ & $3.41 *$ & $8.77 *$ \\
\hline
\end{tabular}

@ Average of six trials

NS-Non-Significant $(\mathrm{P}>0.05 ; *$ - Significant $(\mathrm{P}<0.05)$; ** -Highly significant $(\mathrm{P}<0.01)$; Mean Values bearing different superscripts in a row differ significantly 
Table .3

\begin{tabular}{|l|l|l|l|l|l|l|l|}
\hline Attributes & Control & $\begin{array}{l}\text { T1 } \\
\mathbf{1 0 \%}\end{array}$ & $\begin{array}{l}\mathbf{T 2} \\
\mathbf{2 0 \%}\end{array}$ & $\begin{array}{l}\mathbf{T 3} \\
\mathbf{3 0 \%}\end{array}$ & $\begin{array}{l}\text { T4 } \\
\mathbf{4 0 \%}\end{array}$ & $\begin{array}{l}\text { T5 } \\
\mathbf{5 0 \%}\end{array}$ & F Value \\
\hline Appearance & $7.7 \pm 0.11$ & $6.9 \pm 0.08$ & $7.2 \pm 0.09$ & $7.5 \pm 0.10$ & $6.6 \pm 0.17$ & $6.2 \pm 0.10$ & $1.25^{\mathrm{NS}}$ \\
\hline Taste & $7.1 \pm 0.11$ & $6.9 \pm 0.10$ & $6.7 \pm 0.11$ & $6.6 \pm 0.10$ & $6.3 \pm 0.11$ & $6.0 \pm 0.08$ & $0.71^{\mathrm{NS}}$ \\
\hline Texture & $7.2 \pm 0.09$ & $6.8 \pm 0.07$ & $7.0 \pm 0.21$ & $7.0 \pm 0.18$ & $6.6 \pm 0.15$ & $6.0 \pm 0.13$ & $0.89^{\mathrm{NS}}$ \\
\hline Mouthfeel & $7.2 \pm 0.10$ & $6.7 \pm 0.12$ & $6.8 \pm 0.18$ & $6.9 \pm 0.15$ & $6.3 \pm 0.16$ & $5.7 \pm 0.07$ & $1.02^{\mathrm{NS}}$ \\
\hline $\begin{array}{l}\text { Overall } \\
\text { acceptability }\end{array}$ & $7.6 \pm 0.18$ & $6.9 \pm 0.11$ & $7.0 \pm 0.12$ & $7.2 \pm 0.11$ & $6.4 \pm 0.17$ & $5.9 \pm 0.07$ & \\
\end{tabular}

@ Average of six trials

NS-Non-Significant $(\mathrm{P}>0.05 ; *$ - Significant $(\mathrm{P}<0.05) ; * *$-Highly significant $(\mathrm{P}<0.01)$; Mean Values bearing different superscripts in a row differ significantly

Table.4

\begin{tabular}{|l|l|c|c|c|c|}
\hline $\begin{array}{l}\text { S. } \\
\text { No }\end{array}$ & Constituents & $\begin{array}{c}\text { Corn Grit By-product } \\
\text { (Hominy flour) }\end{array}$ & $\begin{array}{c}\text { Control Pasta (100\% } \\
\text { durum wheat } \\
\text { semolina) }\end{array}$ & $\begin{array}{c}\text { Semolina and Corn } \\
\text { Grit By-product } \\
\text { Pasta (30\%) }\end{array}$ & F Value \\
\hline $\mathbf{1}$ & Moisture content & $11.04 \pm 0.08$ & $11.08 \pm 0.11$ & $11.02 \pm 0.17$ & $1.75^{*}$ \\
\hline $\mathbf{2}$ & Ash content & $1.92 \pm 0.05$ & $1.80 \pm 0.12$ & $2.15 \pm 0.17$ & $0.093^{\mathrm{NS}}$ \\
\hline $\mathbf{3}$ & Crude Fat & $6.28 \pm 0.12$ & $1.22 \pm 0.12$ & $2.02 \pm 0 . .09$ & $5.42^{*}$ \\
\hline $\mathbf{4}$ & Crude Protein & $4.70 \pm 0.15$ & $2.58 \pm 0.22$ & $12.53 \pm 0.11$ & $24.70^{*}$ \\
\hline $\mathbf{5}$ & Total Dietary Fibre & $3.12 \pm 0.010$ & $2.77 \pm 0.25$ & $9.47 \pm 0.21$ & $19.95^{*}$ \\
\hline
\end{tabular}

\section{Acknowledgement}

The authors acknowledge the help provided by the Department of Basic and Applied sciences and Department of Food Engineering, National Institute of Food Technology Entrepreneurship and Management for utilizing the lab facilities for analysis, physical parameters and quality control analysis.

\section{References}

AACC (2000) Approved methods of american association of cerealchemists, 10th edn. The Association St. Paul, MN

IS 11062:1984 Method for estimation ofTotal dietary fibre in foodstuffs
Drewnowski, A., Popkin, B.M., 1997. The nutrition transition: New trends in global diet. Rev 55: 31-42.

Chillo, S., Laverse. J., Falcone, P.M., 2007. Effect of carboxymethylcellulose and pregelatinized corn starch on the quality of amaranthus spaghetti. J Food Eng 83, 492-500.

Chillo, S., Laverse, J., Falcone, P.M., 2008 b. Influence of the addition of buckwheat flour and durum wheat bran on spaghetti quality. J Cereal Sci 47: 144152.

Cubadda, R., 1994. Nutritional value of pasta. Effects of processing conditions. Ital Food Bev Technol:3, 27-33.

Kaur, G., 2009. Development of technology for dietetic pasta. 
Slavin, J., 2004. Whole grain and human health. Nutr Res, Rev 17: 99-100.

Ugarcic-Hardi, Z., Hackenberger, D., Drago, S., Jovica, H., 2003. Effect of soy, maize and extruded maize flour addition on physical and sensory characteristics of pasta. Ital J Food Sci 15: 277-286.

Sabanis, D., Makri, E., 2006. Effect of durum flour enrichment with chickpea flour on the characteristics of dough and lasagna. J Sci Food Agri 86: 19381944.

Ziobro, R., Witczak, T., Leslaw, J., 2013. Supplementation of gluten free bread with non-gluten protein, effect of dough rheological properties and bread characteristics. Food Hydrocolloids 32: 213-220.

\section{How to cite this article:}

Ram Mohan M., N. Sahana and Bhaswati Bhattacharya 2019. Optimization and Quality Evaluation of Pasta Utilizing Corn Grits By-Product (Hominy Flour). Int.J.Curr.Microbiol.App.Sci. 8(09): 1793-1800. doi: https://doi.org/10.20546/ijcmas.2019.809.207 